\title{
Portal Triad
}

National Cancer Institute

\section{Source}

National Cancer Institute. Portal Triad. NCI Thesaurus. Code C33342.

An anatomical unit of hepatic tissue, composed of an interlobular vein of liver, an

interlobular artery of liver and an interlobular bile duct. The triads are embedded in the interlobular connective tissue and travel together throug hout the liver parenchyma. 